\title{
Insuring against climate
}

\author{
Negotiators push for policies to help weather natural disasters.
}

Farmers in the Ethiopian village of Adi Ha have been busy sowing fresh crops of grain in recent weeks, as is customary when their maize crops struggle because of drought. But this year, they have a second backstop against hunger: insurance.

In Adi Ha, farmers can pay a onetime fee of US\$5 to $\$ 30$ to cover their crops of the grain teff, used to produce the flatbread injera. Depending on how much rain falls on this particular swath of the northern highlands in August and September, policies pay out up to five times the premium. The arbiter will be a satellite, marking the first time that scientists have used space-based observations to fashion contracts at the level of individual farmers.

Unlike standard crop insurance, which requires on-the-ground audits, any payments will be distributed automatically according to a set formula, helping villagers to keep food on the table and buy seeds to start over again next year. "Teff is insurance for these farmers, so by insuring teff we are strengthening their insurance," says Daniel Osgood, a researcher who helped develop the policy at Columbia University's International Research Institute for Climate and Society in New York. Oxfam America and the insurance giant Swiss Re are also involved.

Adi $\mathrm{Ha}$ is one of dozens of pilot 'index insurance' programmes that are popping up throughout the developing world as governments, non-profit groups and aid agencies look for ways to help poor communities - and in some cases countries - cope with natural disasters. The idea has now taken root in the United Nations' climate talks; many delegates will be pushing to incorporate insurance policies into a deal at the climate summit in Copenhagen this December.

Leading the effort is the Munich Climate Insurance Initiative (MCII), whose members include reinsurance companies, research groups and agencies such as the United Nations Development Programme. The MCII's proposal combines incentives to help communities prepare for natural disasters in a two-tiered programme: a climate-insurance pool would pay for major disasters in developing countries, and a second tier would promote publicprivate insurance systems to pay for broader implementation of index and other types of insurance programme.

All told, the proposal could cost around $\$ 10$ billion annually, says Koko Warner of the United Nations University in Bonn, Germany, who manages the MCII initiative. "The hook would be that in order to qualify for insurance programmes, countries would have to show that they are actively engaged in risk reduction," she says. "Developing countries agree to reduce their risk, and then developed countries would

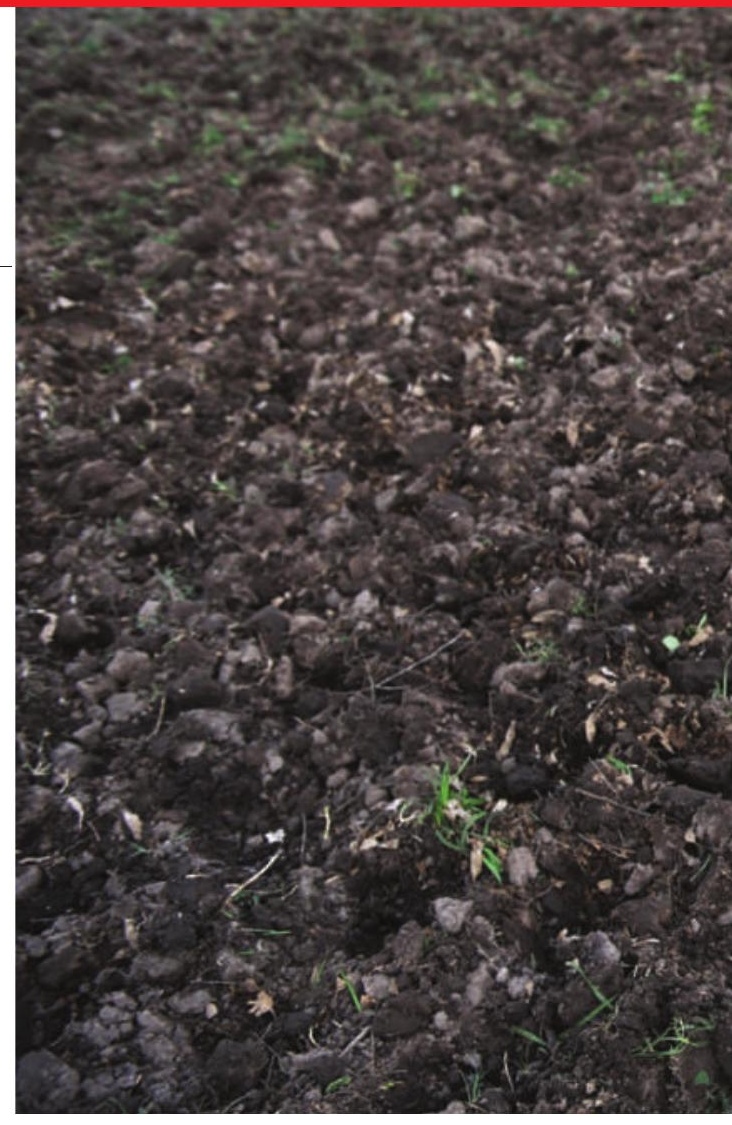

provide an insurance package."

Warner says that references to climate insurance go all the way back to the original United Nations Framework Convention on Climate Change signed in Rio de Janeiro in 1992, but only in the past couple of years has the concept really been integrated into international climate negotiations. In addition to fairly widespread support among developing nations, the European Union has said that it is willing to explore the idea, Warner says, and the steadfast opposition from the United States during the George W. Bush administration has softened under President Barack Obama.

Perhaps the biggest stumbling block is the hard-line position being taken by island

\section{US Congress revives hydrogen vehicle research}

US funding for hydrogen-fuelled transportation research got a boost on 17 July as the House of Representatives voted to restore $\$ 85$ million to the research budget. The administration of President Barack Obama had proposed cutting the funds altogether.

In May, energy secretary Steven Chu sparked an uproar when he proposed slashing current spending on research into hydrogen-based energy technology by $60 \%$, from $\$ 168$ million this fiscal year to $\$ 68$ million in 2010 , and cutting funding entirely for work on hydrogen vehicles. Former president George W. Bush made hydrogen transportation a cornerstone of his energy research strategy, but Chu said biofuels and batteries offer a better short-term pathway to reducing oil use and greenhouse-gas emissions.

Advocates both among scientists and on Capitol Hill have rushed to defend the hydrogen programme in recent weeks. It seems to have worked: the House included a total of \$153 million for hydrogen-energy research in its version of the $\mathbf{2 0 1 0}$ energy and water spending bill.
In the Senate, appropriators have provided $\$ 190$ million for hydrogen research - a $13 \%$ increase over the base budget for 2009 - although the full Senate has yet to take up the legislation. A final bill is unlikely to come for another few months, but some level of funding for hydrogen vehicle research is likely to survive.

Also last week, a National Research Council (NRC) panel weighed in on the debate with a preliminary report on the FreedomCAR and Fuel Partnership, a research consortium involving industry and government. The
NRC committee endorsed the general thrust of the transportation research agenda of the Department of Energy (DOE) but said it is concerned about efforts to scale back work on hydrogen-fuelled transport. Citing the long-term potential of hydrogen fuel cells, the panel said it is not yet clear which vehicle technologies will prevail in the market.

"There was no disagreement on the DOE's approach to put more emphasis on nearer-term technologies, but we felt that the long-term, high-risk, high-payoff 
